Original Research

\title{
Quantification of Mortality Associated with Particulate Matter Using Air Q model in Ambient Air in Shiraz, Iran
}

\author{
Shiva Al-Sadat Tabibzadeh ${ }^{1}$, Seyed Ahmad Hosseini ${ }^{1 *}$, Parviz Mohammadi2**, \\ Alireza Etminan ${ }^{3}$, Hossein Norouzi ${ }^{1}$ \\ ${ }^{1}$ Department of Environment and Natural Resources, Kermanshah Branch, Islamic Azad University, Kermanshah, Iran \\ ${ }^{2}$ Department of Environmental Health Engineering, School of Public Health, Kermanshah University \\ of Medical Sciences, Kermanshah, Iran \\ ${ }^{3}$ Department of Plant Breeding and Biotechnology, Kermanshah Branch, Islamic Azad University, Kermanshah, Iran
}

Received: 7 May 2021

Accepted: 24 June 2021

\begin{abstract}
Suspended particles of less than $10 \mu \mathrm{m}\left(\mathrm{PM}_{10}\right)$ are one of the most important pollutants that create irretrievable damage to human health and the environment. This study surveyed the death rate associated with cardiovascular and respiratory diseases related to $\mathrm{PM}_{10}$. Three sampling stations were selected from various parts of Shiraz, Iran (Southwest of Iran). The concentration of $\mathrm{PM}_{10}$ particles was measured using a Grimm machine. The values of temperature and pressure were also obtained from the Metrological Organization of Shiraz. The data were initially processed in Excel, including pressure and temperature correction, programming, processing (calculating averages), and filtering. The input was entered into AirQ+ and Air Quality Health Impact Assessment model. This model consists of four input parameters (Parameter, Location, AQ data, Supplier) and produces two outputs in the format of tables and graphs. The results presented that the highest share of health impacts attribute to pollutants of air in Shiraz is due to $\mathrm{PM}_{10}$ pollution. The harmful health effects of $\mathrm{PM}_{10}$ significantly increases at concentrations exceeding $40 \mu \mathrm{g} / \mathrm{m}^{3}$. The model revealed that the death number of respiratory and cardiovascular diseases attributed to the $\mathrm{PM}_{10}$ in Shiraz in 2019 was 92 and 22 respectively, which accounts for $2.4 \%$ of the total deaths in Shiraz. It should be concluded that the lack of management for particulate matter pollution can bring about more deaths and cause other health effects.
\end{abstract}

Keywords: mortality, respiratory disease, cardiovascular disease, suspended particles, Shiraz

*e-mail: a.hosseini@iau.ac.ir
**e-mail: parviz8855@yahoo.com 


\section{Introduction}

Air pollution is considered a carcinogen agent which causes a serious problem for human health. In recent decades, some researchers have reported the adverse impacts of pollution of air on human beings all over the world [1-3]. Suspended particles are considered as an important air pollutants which can lead to irritation in the nose, throat, and eyes, nausea, headaches, respiratory infections, lung cancer, chronic respiratory diseases, allergic reactions, heart disease, and high mortality [4]. Particles especially what have less than $10 \mu \mathrm{m}$ of aerodynamic diameter $\left(\mathrm{PM}_{10}\right)$ shows the maximum health effects because of their capability to penetrate the pulmonary alveoli. As a result, the International Cancer Research Agency considered the suspended particles as part of group 1 carcinogens in 2013 [5]. The particles chemical composition and size have a significant role in the health impacts of them. $\mathrm{PM}_{10}$ Exposure enlarges the heart and respiratory diseases rate based on the World Health Organization reports [6, 7]. The National Ambient Air Quality Standard (NAAQS) was set the primary daily standard for $\mathrm{PM}_{10}$ of outdoor air as value as $150 \mu \mathrm{g} / \mathrm{m}^{3}$ [1]. In addition, WHO set the annual mean standard and average daily permissible airborne concentrations for $\mathrm{PM}_{10}$ particles as $20 \mu \mathrm{g} / \mathrm{m}^{3}$ and $50 \mu \mathrm{g} / \mathrm{m}^{3}$ because of the health impacts of these particles $[6,8]$. It should be noted that these values should not occur more than 35 days per year. More evidence have been risen for the mortality associated to the pollutants of ambient air as long-term exposure [9, 10]. Comprehensive studies have been carried out for cardiovascular diseases related to the long-and short- term exposure to $\mathrm{PM}_{10}$ [11]. Recently, these researches have critically improved our perceptions of mechanisms that can clearly elucidate the attributions observed in experimental and epidemiological surveys related to mortality and air pollution [12]. Traffic emissions considered as main source of gaseous and particles pollutants like sulphur oxides $\left(\mathrm{SO}_{2}\right)$ and oxides of nitrogen in urban areas. Besides, exposure to these pollutant inconsistences associated to the traffic emissions could rarely presented by the amount of particulate matter due to the high regional background concentration of these pollutant associated to the other sources [13]. Nevertheless, more certain markers could be for the pollutants related to the traffic such as elemental carbon and ultrafine particle number [14]. Some approaches for control of emissions from the traffic sources could significantly decline these emissions, and therefore emissions of nontailpipe sources such as emissions of engine crankcase (lubricating oil of combusted), brake wear, tire, and road have converted to be more important. Research related to the emissions of traffic in the Netherlands revealed that addition in the mount of pollutants in major roads related to tire and brake wear $(\mathrm{Cu}, \mathrm{Zn})$ as well as ultrafine particles and soot in comparison with urban background [15].
The city of Shiraz which the population of it estimate about 1.87 million people, considers as a metropolises city in Iran, placed in a semi-warm area of Iran (southwest of Iran). The industrial areas presence, the activity of a cement factory, a vegetable oil factory, and power plants, Shiraz is one of the industrialized cities in Iran. The geographical location of the city, prevailing local and regional winds and the effects of drought have made the city in terms of air pollution as a most polluted region. The results of a AQI study in Shiraz showed that $\mathrm{PM}_{10}$ was responsible for air pollution in Shiraz in $18 \%$ of days which had an AQI $>50$ (moderate air quality or worse). Due to the lack of a scientific and comprehensive study on the air pollution and its effects on human being in Shiraz, present work attempts to estimate the number of deaths from respiratory and cardiovascular diseases resulted in due to exposure of $\mathrm{PM}_{10}$ in Shiraz. Therefore, this study was sampled the suspended particles at 4 stations in 2019, and estimate the respiratory and cardiovascular mortality in Shiraz, and provided the necessary information for the city's municipal management and health department to control air pollution.

\section{Materials and Methods}

\section{Study Area}

Shiraz as a studied area is placed in the central part of Fars province with a total area of 178 square kilometers $\left(29^{\circ} 36^{\prime}\right.$ north and $52^{\circ} 32^{\prime}$ east, at an above sea altitude of 1486 meters). The average temperature of the warmest (July) and coldest months (January) are $30^{\circ} \mathrm{C}, 5^{\circ} \mathrm{C}$, respectively. Shiraz contain a mild Mediterranean climate. The average annual temperature is $18^{\circ} \mathrm{C}$ and annual rainfall in Shiraz is $337.8 \mathrm{~mm}$. Suspended particle data were collected through the city's Department of Environment. The sampling points and characterization of studied area are shown in Fig. 1.

The characterizations of the population following age groups were collected from the national Center of Statistic of Iran. Besides, the deaths number that were categorized based on age were earned via the Office of Civil Registration in Shiraz. All mortalities and mortality rates of baseline incidence (BI) occurred due to COPD, IHD, ALRI, stroke, and LC were estimated through the information of the Office of Civil Registration of Shiraz as well as Shiraz University of Medical Sciences.

\section{Modeling and Exposure Assessment}

The present study was a quantitative study that was attributed to the impacts of $\mathrm{PM}_{10}$ on human health in Shiraz using a modeling approach. Modeling was developed using data that was collected via the Meteorological Organization and Department of Environment of Shiraz. The stations of sampling were 


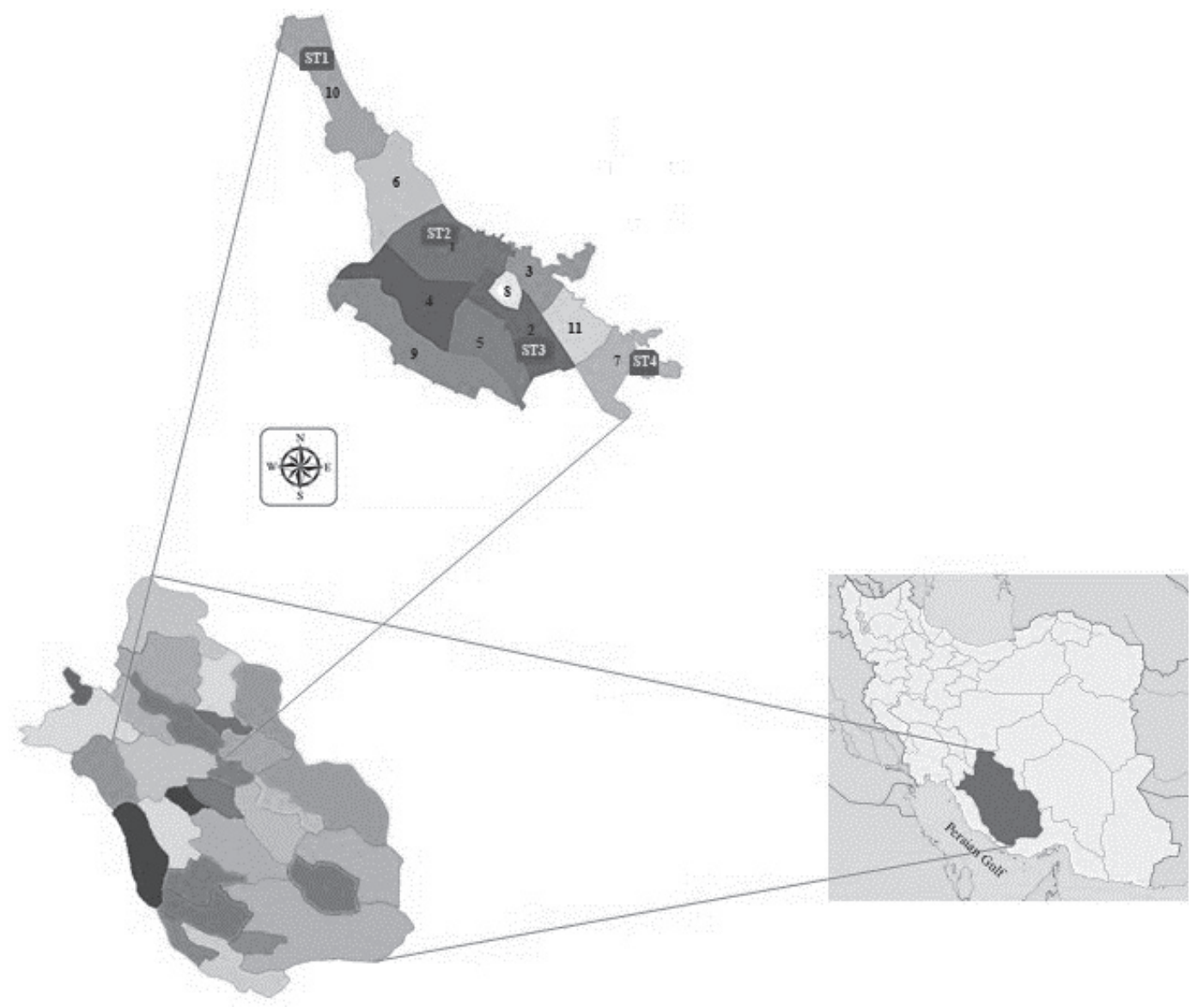

Fig. 1. Studied area location and sampling points.

chosen according to the EPA criteria and four sample points were chosen for sampling. The concentration of $\mathrm{PM}_{10}$ was measured using a Grim machine [16]. The Grim machine uses the air sheathing system and displays real-time aerosol mass readings. This device was equipped with software for transferring data to a PC with an RS232 cable and displayed data graphically as two numeric formats [17]. Since the pollution control stations lacked temperature sensors, meteorological data was collected for this purpose from the Meteorological Organization of Shiraz. After that, data were analyzed in Microsoft EXCEL and the result have input into the Air Q model. To prepare model input, different steps were taken to adjust temperature and pressure, adapt units to the model, perform primary and secondary processing, calculate daily averages, carry out condition correction, and perform primary and secondary filtering. Air Q requires four inputs (Parameter, Location, AQ data, Supplier) and generates two graphs. Features and advantages of the Air Q model include: encompassing features of other models such as CMAQ and ORAM, and the ability to make evaluation using all reference pollutants. One of the most important features of the Air Q model is its ability to generate risk of relative (RR, the likelihood ratio of a complication in the exposed population to the possibility of the same complication in the non-exposed group) [18]. The relative risk was calculated through the following equation.

$$
R R=\exp \left[\beta \ln \left(x-x_{0}\right)\right]
$$

...where $\beta$ is a confidence interval which was considered $95 \%, x$ and $x_{o}$ refer to the concentration of pollutants and the value of the counterfactual, respectively.

Attributed proportion (AP, percentage of health consequences directly attributable to the pollutant) [1] and the baseline incidence (BI, the number of cases within one year), were calculated based on epidemiological studies conducted by the WHO and systematic reviews. The Air Q model is particularly suitable for industrialized cities such as Shiraz $[4,18]$. AP is part of health outcomes that can be attributed to specific demographic exposures over a given time (on the assumption of a link between exposure and health outcome in the distorting influence absence) [19]. This component can be computed by the following equation:

$$
A P=\frac{S U M[(R R(C)-1) \times P(C)]}{S U M[R R(C) \times P(C)]}
$$

RR (C) and P (C) represent the relative risk of health outcomes in target group or group $\mathrm{C}$ and population ratio of target group or group c, respectively. 
Besides, the number of cases per population (BE) could be estimated with the following equation.

$$
B E=B \times A P
$$

...where $\mathrm{B}$ represents a certain baseline incidence. $\mathrm{RR}$ is reported in three forms; lower limit relative risk (having a positive and desirable effect in reducing complications), the middle limit relative risk, and the upper limit relative risk (having a negative and undesirable effect on increasing the incidence of complications) [20]. Based on the confidence intervals (CI: $95 \%$ ) of the estimation of relative risk in the calculations, it can determine the number range of the expected cases and the lower and upper limits of the estimated component.

\section{Results and Discussion}

In 2019, the annual average concentration, mean concentration in summer and winter, and $98^{\text {th }}$ percentile for $\mathrm{PM}_{10}$ were $43.8,53,31$, and $140 \mu \mathrm{g} / \mathrm{m}^{3}$, respectively. The average amount of suspended particles at warm seasons (spring and summer) was lower than the cold seasons (autumn and winter). Dust storms in the western areas of the Middle East and human activities were the main source of pollutants [21]. The amount of cardiovascular deaths because of $\mathrm{PM}_{10}$ was calculated to be 92 people in 2019, with a baseline incidence (BI) of 216 per one thousand individuals (Table 1).

In Table 2, relative risk indicators, attributable component, baseline incidence, and the amount of cases associated to particulate matter $\left(\mathrm{PM}_{10}\right)$ pollution for respiratory disease deaths are presented. Baseline incidence was assumed to be 36 cases per one hundred thousand individuals. According to the findings presented in Table 2, the cumulative incidence of respiratory death in Shiraz was 22 individuals.
Fig. 2 and 3 are plotted according to the quantitative analysis and cumulative number of health outcomes impacted by the concentration of pollutant. As can be observed in these Figs, the three lines attributed to the relative risk (RR) associated with $\mathrm{PM}_{10}$ at the lower, middle, and upper limits. Fig. 1 presents that the cumulative mortality rate related to the cardiovascular disease due to $\mathrm{PM}_{10}$ was 92 individuals in 2019. Besides, an increasing trend in cumulative mortality of people in Shiraz was emerged less steep for concentrations higher than $60 \mu \mathrm{g} / \mathrm{m}^{3}$ (Fig. 1) for concentration of $\mathrm{PM}_{10}$ between 10 to $60 \mu \mathrm{g} / \mathrm{m}^{3}$. Fig. 2 shows the death number related to the respiratory diseases in the various concentrations of $\mathrm{PM}_{10}$ at the three limits. As shown in Fig. 2, the cumulative death number due to respiratory illness enlarged with an increase in the concentration of $\mathrm{PM}_{10}$. The death number rose sharply for concentrations between 10 to $40 \mu \mathrm{g} / \mathrm{m}^{3}$ and somewhat plateaus later. It can be seen that about $50 \%$ of mortality occurred per day with a $\mathrm{PM}_{10}$ concentration of less than $50 \mu \mathrm{g} / \mathrm{m}^{3}$ (Fig. 2).

The results showed that the cardiovascular death number associated to particles less than $10 \mu \mathrm{m}$ in Shiraz was 92 based on the $\mathrm{BI}=216$ (per one hundred thousand individuals). It reflected that the risk of cardiovascular death enhanced with $4 \%$ per $1 \mu \mathrm{g} / \mathrm{m}^{3}$ addition in the concentration of $\mathrm{PM}_{10}$. It is worth to note that about $70 \%$ of cardiovascular deaths per day have been carried out during the concentration of $\mathrm{PM}_{10}$ was less than $60 \mu \mathrm{g} / \mathrm{m}^{3}$.

The death number due to respiratory diseases was 22 which $53 \%$ of them occurred at concentrations below $40 \mu \mathrm{g} / \mathrm{m}^{3}$. The large attributable factor in number of death due to pulmonary problems represented an elevated relative risk (64 individuals). Despite the presence of some relative risk, the health impacts of $\mathrm{PM}_{10}$ exposure at concentrations of less than $10 \mu \mathrm{g} / \mathrm{m}^{3}$ was zero due to the population didn't expose to these concentrations. It should be mentioned that the $\mathrm{PM}_{10}$

Table 1. Estimation of total cardiovascular mortality based on relative risk, attributable cases and attributable component due to $\mathrm{PM}_{10}$ pollution in 2019, in Shiraz (BI = 216).

\begin{tabular}{|c|c|c|}
\hline Relative Risk (upper limit) & Attributable proportion (percent) & Total count (individuals) \\
\hline Lower limit (1.005) & 1.66 & 58 \\
\hline Middle limit (1.008) & 2.63 & 92 \\
\hline Upper limit (1.018) & 5.74 & 200 \\
\hline
\end{tabular}

Table 2. Estimation of total mortality of pulmonary based on the relative risk, total attributable individuals and attributable proportion (\%) due to $\mathrm{PM}_{10}$ pollution in 2019, in Shiraz $(\mathrm{BI}=36)$.

\begin{tabular}{|c|c|c|}
\hline Relative Risk (upper limit) & Attributable proportion (percent) & Total count (individuals) \\
\hline Lower limit (1.008) & 2.63 & 15 \\
\hline Middle limit (1.012) & 3.90 & 22 \\
\hline Upper limit (1.037) & 11.12 & 64 \\
\hline
\end{tabular}




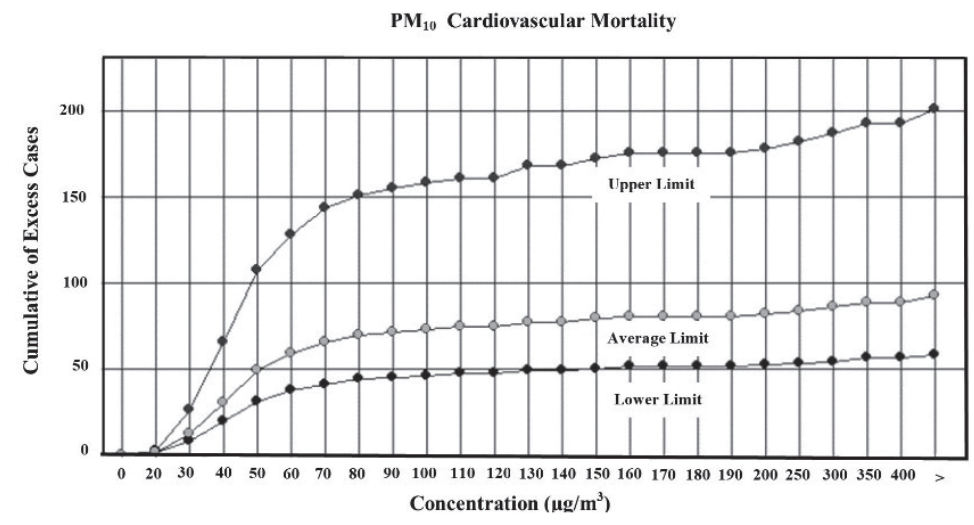

Fig. 2. Correlation of the cumulative mortality rate of cardiovascular diseases attributed to $\mathrm{PM}_{10}$ versus concentration of $\mathrm{PM}_{10}$.

PM$_{10}$ Respiratory Mortality

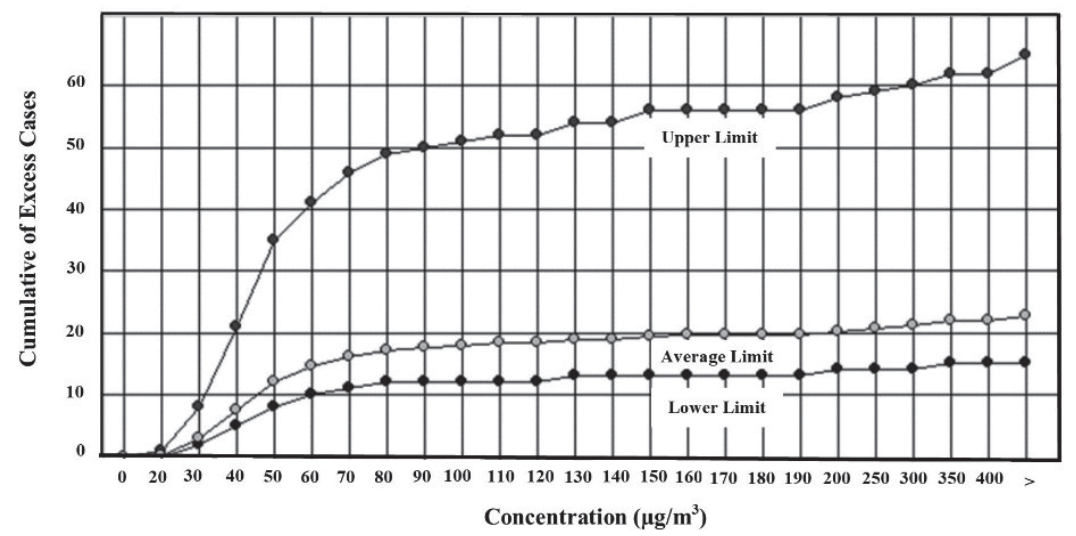

Fig. 3. Correlation of cumulative mortality rate of respiratory diseases associated to $\mathrm{PM}_{10}$ versus concentration of $\mathrm{PM}_{10}$.

concentration less than $10 \mu \mathrm{g} / \mathrm{m}^{3}$ has never occurred for 2019. Based on the results, the annual average of $\mathrm{PM}_{10}$ in Shiraz in 2019 was $43.8 \mu \mathrm{g} / \mathrm{m}^{3}$. The concentration of this pollutant exceeded the WHO limit in $18 \%$ of days in this year. The high levels of $\mathrm{PM}_{10}$ in Shiraz were created by high levels of fossil fuel consumption due to the region's cold climate, high per capita car ownership, the tropospheric inversion, and the dust caused by neighboring countries. The number of deaths and diseases attributed to the different concentrations of pollutants was linked to the relative risk and the number of days was exposed to a given concentration. According to the Air Q evaluation, the highest total deaths from cardiovascular and pulmonary diseases associated with $\mathrm{PM}_{10}$ pollution occurred at concentrations between $49-40 \mu \mathrm{g} / \mathrm{m}^{3}$. However, only $5 \%$ of the days in 2019 had concentrations in this range.

Besides, the death number in Shiraz city attributed to the suspended particles due to the various disease is shown in Table 3. According to the obtained results, suspended particles could increase the number of deaths related to heart ischemia more than other diseases. The findings of air pollution study in Mashhad city (northeast of Iran) were in line with this study [22].
Table 4 shows the average number of total deaths in Shiraz attributed to $\mathrm{PM}_{10}$ in 2019 in a population of higher than 30 years. As can be seen, there are about 531 total deaths might be attributed to the longterm exposure to $\mathrm{PM}_{10}$ in the average concentration of $27.7 \mu \mathrm{g} / \mathrm{m}^{3}$ during the studied time. In other words, there were 31 deaths per 100000 people in Shiraz which were related to the exposure of long-term to this pollutant. It should be mentioned that this number of death was less than the average death number in the world (53 per person) attributed to the $\mathrm{PM}_{10}$ exposures [23]. There is a finding that showed the Exposure of long-term to $\mathrm{PM}_{2.5}$ in Tehran causes 128 deaths per 100000 people (in 2018) which was much more than the world average and this study calculated [24]. In addition, the results of another study showed that total death in Tehran related to the $\mathrm{PM}_{2.5}$ in a 10 -year study was between 3755 to 5895 per year [25]. According to the results, the maximum death is associated with brain stroke. It merits to note that many studies reported that the correlation between stroke and exposure the air pollutants is significant [26, 27]. Based on the previous study, the maximum occurrence of stroke was occurred in winter, as the amount of air pollutants is high [26]. 
Table 3. The base death rate in Shiraz (2019) (Total population: 1712745 and total death: 8291).

\begin{tabular}{|c|c|c|c|c|c|}
\hline Parameter & Basic & COPD & $\begin{array}{c}\text { Lung } \\
\text { cancer }\end{array}$ & $\begin{array}{c}\text { Heart } \\
\text { ischemia }\end{array}$ & $\begin{array}{c}\text { Brain } \\
\text { stroke }\end{array}$ \\
\hline Number of deaths for population between 25 to 60 & 7739 & 19 & 36 & 138 & 110 \\
\hline Total population between 25 to 60 & 773459 & 773459 & 773459 & 956436 & 956436 \\
\hline Total number of deaths in the population between 25 to 60 & 246 & 3.4 & 4.6 & 14.4 & 11.05 \\
\hline $\begin{array}{c}\text { Total number of deaths in the population over 60 years without an } \\
\text { accident }\end{array}$ & 4797 & 158 & 97 & 597 & 393 \\
\hline Total number of populations over 60 years & 171612 & 171612 & 171612 & 171612 & 171612 \\
\hline Total death in the population of over 60 year & 279 & 92 & 56.52 & 347.8 & 229 \\
\hline $\begin{array}{c}\text { Total death in the population of over 60 years without accident } \\
\text { per 100000 persons }\end{array}$ & 709 & 19.57 & 14.7 & 65.15 & 44.59 \\
\hline
\end{tabular}

Also, the large-scale study suggested that there is a correlation between the stroke rate related to air pollution and racial differences and geographic characteristics [28]. It was found that a high amount of particulate matter in the air could lead to an increase in the admitted persons to the hospital due to hemorrhagic and ischemic stroke [29]. According to the previous study, it was shown that the highest association between particulate matters and death rate related to them could be attributed to the stroke in Tehran [25]. It was found that the binding protein of lipopolysaccharide prevented the induction of cytokine through $\mathrm{PM}_{2.5-10}$ and this suggests bacteria of gram-negative is a component of $\mathrm{PM}_{2.5-10}$. Besides, the synergetic effect of the suspended matter and endotoxin proinflammatory related to the macrophages could cause the homeostasis of lung tissue [30]. In addition, it was reported that high rate of respiratory disease caused by air pollution may be due to pneumonia [31, 32].

It was apperceived that there was an increase $(0.25 \%)$ in total mortality of ischemic heart disease due to an addition in each $10 \mu \mathrm{g} / \mathrm{m}^{3}$ of particulate matter with size of less than $2.5 \mu \mathrm{m}\left(\mathrm{PM}_{2.5}\right)$ in Tehran [24]. The average death attributed to disease of ischemic heart because of exposure of long-term to $\mathrm{PM}_{10}$ in Shiraz was
380 persons. Therefore, the results of this study were lower than the mortality obtained from a previous study in Tehran [25].

Particulate matter could cause epigenetic variations in LC like rising in cytokines and some cells of inflammatory, small, and non-small cell lung cancer [24]. The high values of $\mathrm{PM}_{10}$ in the air could lead to oxidative stress and release of cytokine which could be remarked as the primary mechanism for improving asthma, COPD, and LC. Besides, an increase in autophagocytosis and tumor cells might be attributed to the increment in amount of $\mathrm{PM}_{10}$ in air and then LC [33]. It was found that there is a significant correlation between LC mortality and exposure of long-term to $\mathrm{PM}_{10}$ in various regions of the world [34, 35].

The related deaths from COPD attributed to the $\mathrm{PM}_{10}$ in this study were 21 . While the number of deaths associated with the $\mathrm{PM}_{2.5}$ due to COPD in Tehran was 158 persons which much more than the present study. These differences may be due to the concentration of $\mathrm{PM}_{2.5}$ in Tehran [36].

Table 5 shows the health effects of $\mathrm{PM}_{10}$ in 2018 and 2019. Based on the results, the death associated with $\mathrm{PM}_{10}$ in 2019 was less than in 2018. It was reported that the total deaths associated with cardiovascular disease

Table 4. Long-term (chronic) health effects attributed to suspended particles $\mathrm{PM}_{10}$ in Shiraz in 2019.

\begin{tabular}{|c|c|c|c|}
\hline Demographical characteristics & Total Population & $\begin{array}{c}\text { Population (higher than } \\
30 \text { years })\end{array}$ & $\begin{array}{c}\text { Average concentration } \\
\left(\mu \mathrm{g} / \mathrm{m}^{3}\right)\end{array}$ \\
\hline No. & 1712745 & 945071 & 27.7 \\
\hline \multicolumn{2}{|c|}{ Chronic health effect associated with PM ${ }_{10}$} & Lower limit \\
\hline Parameters & Average & Upper limit & 351 \\
\hline Total deaths & 531 & 694 & 8 \\
\hline Death associated with COPD & 21 & 33 & 278 \\
\hline Death associated with lung cancer & 18 & 30 & 112 \\
\hline Death associated with heart ischemia & 380 & 463 & 340 \\
\hline
\end{tabular}


Table 5. Air pollution effects attributed to $\mathrm{PM}_{10}$.

\begin{tabular}{|c|c|c|c|c|}
\hline \multirow{2}{*}{ Effects } & \multicolumn{2}{|c|}{ Number } & \multirow{2}{*}{$\begin{array}{l}\text { Attributed component } \\
\qquad(\%)\end{array}$} & \multirow{2}{*}{$\begin{array}{c}\text { Decrease/increase } \\
\text { than } 2018\end{array}$} \\
\hline & 2018 & 2019 & & \\
\hline Total deaths & 278 & 249 & 2.44 & -10 \\
\hline Death due to cardiovascular disease & 102 & 92 & 2.63 & -9.8 \\
\hline Death due to respiratory disease & 25 & 22 & 3.9 & -12 \\
\hline Hospitalization due to respiratory disease & 599 & 538 & 2.63 & -10.18 \\
\hline Hospitalization due to cardiovascular disease & 232 & 208 & 2.95 & -10.34 \\
\hline
\end{tabular}

in Baja California, southeast Texas, and Southwest US increased by $3.1 \%$ for $\mathrm{PM}_{10}$ and $2.8 \%$ for $\mathrm{PM}_{10-2.5}$ [32].

A large amount of researches were carried out for estimating the impacts of health due to pollution of air using the Air Q 2.2.3 and Air Q+ models in Iran [37, 38]. These studies represented that air pollution has negatively influenced on health in the first three years because of extremely dusty storms. Studies in many cities in Europe, America, and Asian countries revealed that the short-term exposure of $\mathrm{PM}_{10}$ had the similar health effects. It was reported that the risk of death increases with daily concentration of $\mathrm{PM}_{10}$ by 0.5 percent per $10 \mu \mathrm{g} / \mathrm{m}^{3}$ [39-41]. The health impacts of airborne pollutants, in particular $\mathrm{PM}_{10}$ were evaluated in Ukraine. The results showed that total deaths was about 46,000 which more than half of them was associated to the cardiovascular disease and lung cancer [41].

It is worth mentioning that this study had some limitations such as pollutants were studied in isolation and it was considered that the obtained concentrations at the sampling points indicate the average exposure of the people living in Shiraz. Therefore, the results of this study should be taken into consideration with caution by experts [6].

\section{Conclusion}

The present study represented that mortality related to the $\mathrm{PM}_{10}$ pollution in Shiraz due to heart attack and respiratory problem were about $2.6 \%$ and $3.9 \%$, respectively. The death number related to the respiratory disease as well as cardiovascular problems were calculated by the Air Q model clearly illustrated the effects of $\mathrm{PM}_{10}$ on the health of exposed individuals in Shiraz. The results underscored the importance of a management plan for air pollution and the necessity of sustainable development in the city. Pollution reduction measures such as mulching and reduction of emissions from the main sources of particulate matter pollution, it is possible to mitigate the health effects of this pollutant and lower the current risk level (the upper limit) to a more favorable situation (the lower limit). Lack of management for particulate matter pollution can bring about more deaths and cause other health effects.
Further epidemiological studies are needed to estimate the actual impacts of air pollutants by calculating some statistical components such as the attributable component and relative risk (RR) index and baseline incidence (BI).

On the other hand, air pollution considered as the challenges of urbanization and industrialization that could influence the human lives all over the world. Numerous epidemiological studies revealed the correlation between mortality and air pollutants. There is also a famine in the studies that show the general air pollutant health impacts in the region. It was reported by WHO that missing data could significantly have carried out during the maintenance periods or times as measuring devices are turned off. Therefore, the results of epidemiological studies could be influenced by the data obtained from these situations and devices. Thus, the new, credible and scientific standard of air quality must be set for Iran. According to the geographical characteristics of the country, frequent dust storms and low precipitation, the standards of $\mathrm{PM}_{10}$ pollutants require to be revised.

\section{Acknowledgment}

The authors would like to express their special thanks to the Iranian Meteorological Organization and Department of Environment of Shiraz for collaboration on this study.

\section{Conflict of Interest}

The authors declare no conflict of interest.

\section{References}

1. GERAVANDI S., TAKDASTAN A., ZALLAGHI E., NIRI M.V., MOHAMMADI M.J., SAKI H., NAIEMABADI A. Noise pollution and health effects, Jundishapur J. Health Sci. 7 (1), 2015.

2. MOKHTARI M., MIRI M., MOHAMMADI A., KHORSANDI H., HAJIZADEH Y., ABDOLAHNEJAD A. Assessment of air quality index and health impact of 
$\mathrm{PM}_{10}, \mathrm{PM}_{25}$ and $\mathrm{SO}_{2}$ in Yazd, Iran, J. Mazandaran Univ. Med. Sci. 25 (131), 14, 2015.

3. THACH T.-Q., TSANG H., CAO P., HO L.-M. A novel method to construct an air quality index based on air pollution profiles, Int. j. Hyg. Environ. Health. 221 (1), 17, 2018.

4. GOUDARZI G., GERAVANDI S., VOSOUGHI M., JAVAD MOHAMMADI M., SADAT TAGHAVIRAD S. Cardiovascular deaths related to Carbon monoxide Exposure in Ahvaz, Iran, Iran. j. health saf. environ. 1 (3), 126, 2014.

5. KIM K.-H., KABIR E., KABIR S. A review on the human health impact of airborne particulate matter, J. Environ. int. 74, 136, 2015.

6. WHO. Ambient air pollution: A global assessment of exposure and burden of disease, 2016.

7. GRAHAME T.J., KLEMM R., SCHLESINGER R.B. Public health and components of particulate matter: the changing assessment of black carbon, J. Air Waste Manag. Assoc. 64 (6), 620, 2014.

8. RABIEI K., HOSSEINI S.M., SADEGHI E., JAFARIKOSHKI T., RAHIMI M., SHISHEHFOROUSH M., LAHIJANZADEH A., SADEGHIAN B., MOAZAM E., MOHEBI M.B. Air pollution and cardiovascular and respiratory disease: Rationale and methodology of capacity study, J ARYA Atheroscler. 13 (6), 264, 2017.

9. POPE III C.A., DOCKERY D.W. Health effects of fine particulate air pollution: lines that connect, J. Air Waste manage. Assoc. 56 (6), 709, 2006.

10. WHO. Air quality guidelines: global update 2005: particulate matter, ozone, nitrogen dioxide, and sulfur dioxide. World Health Organization. 2006.

11. HOEK G., KRISHNAN RM., BEELEN R., PETERS A., OSTRO B., BRUNEKREEF B., KAUFMAN J.D. Long-term air pollution exposure and cardio-respiratory mortality: a review, Environ. Health. 12 (1), 1, 2013.

12. BROOK R.D., RAJAGOPALAN S., POPE III C.A., BROOK J.R., BHATNAGAR A., DIEZ-ROUX A.V., HOLGUIN F., HONG Y., LUEPKER R.V., MITTLEMAN M.A. Particulate matter air pollution and cardiovascular disease: an update to the scientific statement from the American Heart Association, J Circulation. 121 (21), 2331, 2010.

13. JANSSEN N.A., HOEK G., SIMIC-LAWSON M., FISCHER P., VAN BREE L., TEN BRINK H, KEUKEN M., ATKINSON R.W., ANDERSON H.R., BRUNEKREEF B. Black carbon as an additional indicator of the adverse health effects of airborne particles compared with $\mathrm{PM}_{10}$ and $\mathrm{PM}_{2.5}$, J Environ. health perspec. 119 (12), 1691, 2011.

14. PETERS A., RÜCKERL R., CYRYS J. Lessons from air pollution epidemiology for studies of engineered nanomaterials, J occup. environ. med. 53, S8, 2011.

15. BOOGAARD H., KOS G.P., WEIJERS E.P., JANSSEN N.A., FISCHER P.H., VAN DER ZEE S.C., DE HARTOG J.J., HOEK G. Contrast in air pollution components between major streets and background locations: particulate matter mass, black carbon, elemental composition, nitrogen oxide and ultrafine particle number, J Atmos. Environ. 45 (3), 650, 2011.

16. HADEI M., HOPKE P.K., NAZARI S.S.H., YARAHMADI M., SHAHSAVANI A., ALIPOUR M.R. Estimation of mortality and hospital admissions attributed to criteria air pollutants in Tehran Metropolis, Iran (2013-2016), J. Aerosol Air Qual. Res. 17, 2474, 2017.
17. DOMINICK D., JUAHIR H., LATIF M.T., ZAIN S.M., ARIS A.Z. Spatial assessment of air quality patterns in Malaysia using multivariate analysis, J Atmos. Environ. 60, 172, 2012

18. MOHAMMADI M.J., GOUDARZI G., GERAVANDI S., YARI A.R., GHALANI B., SHIRALI S., ZALLAGHI E., ESMAILI M. Dispersion modeling of nitrogen dioxide in ambient air of Ahvaz city, J. Health Scope. 5 (2), 2016.

19. ZALLAGHI E., GOUDARZI G., GERAVANDI S., MOHAMMADI M.J.. Epidemiological indexes attributed to particulates with less than 10 micrometers in the air of Ahvaz City during 2010 to 2013, J Health Scope. 3 (4), 2014.

20. ZALLAGHI E., GOUDARZI G., HADDAD M.N., MOOSAVIAN S.M., MOHAMMADI M.J. Assessing theEffects of nitrogen dioxide in urban air on health of west and southwest cities of Iran, J. Health Sci. 6 (4), 2014.

21. HADEI M., HOPKE P.K., NAZARI S.S.H., YARAHMADI M., SHAHSAVANI A., ALIPOUR M.R. Estimation of mortality and hospital admissions attributed to criteria air pollutants in Tehran Metropolis, Iran (20132016), J Aerosol Air Qual. Res. 17, 2474, 2017.

22. BONYADI Z., EHRAMPOUSH M.H., GHANEIAN M.T., MOKHTARI M., SADEGHI A. Cardiovascular, respiratory, and total mortality attributed to $\mathrm{PM}_{2.5}$ in Mashhad, Iran, J Environ. Monitor. Assess. 188 (10), 570, 2016.

23. WHO. Burden of disease from household air pollution for 2012, 2017.

24. ANSARI M., EHRAMPOUSH M.H.J.E.R. Meteorological correlates and AirQ+ health risk assessment of ambient fine particulate matter in Tehran, Iran,Environ. Res. 170, 141, 2019.

25. FARIDI S., SHAMSIPOUR M., KRZYZANOWSKI M., KÜNZLI N., AMINI H., AZIMI F., MALKAWI M., MOMENIHA F., GHOLAMPOUR A., HASSANVAND MSJEI. Long-term trends and health impact of $\mathrm{PM}_{25}$ and $\mathrm{O}_{3}$ in Tehran, Iran, 2006-2015, Environ. Int. 114, 37, 2018.

26. KNEZOVIC M., PINTARIC S., JELAVIC M.M., KES V.B., NESEK V., BOGOVIC S., CVETKOVIC B., PINTARIC HJANB. The role of weather conditions and normal level of air pollution in appearance of stroke in the region of Southeast Europe, Acta Neurol. Belg. 118 (2), 267, 2018.

27. VIVANCO-HIDALGO R.M., WELLENIUS G.A., BASAGAÑA X., CIRACH M., GONZÁlEZ A.G., DE CEBALLOS P., ZABALZA A., JIMÉNEZ-CONDE J., SORIANO-TARRAGA C., GIRALT-STEINHAUER E.J.E.R. Short-term exposure to traffic-related air pollution and ischemic stroke onset in Barcelona, Spain, Environ. Res. 162, 160, 2018.

28. O'NEAL T.W., SOLIMAN E.Z., EFIRD J.T., JUDD S.E., HOWARD V.J., HOWARD G., MCCLURE LAJJOES, EPIDEMIOLOGY E. Fine particulate air pollution and premature atrial contractions: The Reasons for Geographic and Racial Differences in Stroke study, J. Expo. Sci. Environ. Epidemiol. 27 (3), 271, 2017.

29. LIU H., TIAN Y., XU Y., HUANG Z., HUANG C., HU Y., ZHANG J.J.E.P. Association between ambient air pollution and hospitalization for ischemic and hemorrhagic stroke in China: A multicity case-crossover study, Environ. Pollut. 230, 234, 2017.

30. MONN C., BECKER S. Cytotoxicity and Induction of Proinflammatory Cytokines from Human Monocytes Exposed to Fine $\left(\mathrm{PM}_{2.5}\right)$ and Coarse Particles $\left(\mathrm{PM}_{10-2.5}\right)$ in 
Outdoor and Indoor Air, Toxicol. Appl. Pharmacol. 155 (3), 245-52, 1999. doi: https://doi.org/10.1006/taap.1998.8591.

31. TRAN H., KIM J., KIM D., CHOI M., CHOI M. Impact of air pollution on cause-specific mortality in Korea: Results from Bayesian Model Averaging and Principle Component Regression approaches, Sci. Total Environ. 636, 1020, 2018. doi: https://doi.org/10.1016/j.scitotenv.2018.04.273.

32. RODOPOULOU S., CHALBOT M.-C., SAMOLI E., DUBOIS D.W., SAN FILIPPO B.D., KAVOURAS I.G. Air pollution and hospital emergency room and admissions for cardiovascular and respiratory diseases in Doña Ana County, New Mexico, Environ. Res. 129, 39, 2014. doi: https://doi.org/10.1016/j.envres.2013.12.006.

33. WEI H., LIANG F., CHENG W., ZHOU R., WU X., FENG Y., WANG YJET. The mechanisms for lung cancer risk of $\mathrm{PM}_{2.5}$ : Induction of epithelial-mesenchymal transition and cancer stem cell properties in human non-small cell lung cancer cells, Environ. Toxicol. 32 (11), 2341, 2017.

34. POPE III C.A., BURNETT R.T., TURNER M.C., COHEN A., KREWSKI D., JERRETT M., GAPSTUR S.M., THUN M.J.J.E.H.P. Lung cancer and cardiovascular disease mortality associated with ambient air pollution and cigarette smoke: shape of the exposure-response relationships, Environ. Health Perspect. 119 (11), 1616, 2011.

35. HAMRA G.B., GUHA N., COHEN A., LADEN F., RAASCHOU-NIELSEN O., SAMET J.M., VINEIS P., FORASTIERE F., SALDIVA P., YORIFUJI TJEHP. Outdoor particulate matter exposure and lung cancer: a systematic review and meta-analysis, Environ. Health Perspect. 122 (9), 906, 2014.
36. YARAHMADI M., HADEI M., NAZARI S.S.H., CONTI G.O., ALIPOUR M.R., FERRANTE M., SHAHSAVANI A.J.E.S, RESEARCH P. Mortality assessment attributed to long-term exposure to fine particles in ambient air of the megacity of Tehran, Iran, Environ. Sci. Pollut. Res. 25 (14), 14254, 2018.

37. HADEI M., NAZARI S.S.H., YARAHMADI M., KERMANI M., FARHADI M., SHAHSAVANI A. Estimation of gender-specific lung cancer deaths due to exposure to $\mathrm{PM}_{2.5}$ in 10 cities of Iran during 2013-2016: A modeling approach, Int. J. Cancer Manag. e10235. 2017.

38. MIRI M., DERAKHSHAN Z., ALLAHABADI A., AHMADI E., CONTI G.O., FERRANTE M., AVAL H.E. Mortality and morbidity due to exposure to outdoor air pollution in Mashhad metropolis, Iran. The AirQ model approach, J Environ. Res. 151, 451, 2016.

39. SAMOLI E., ATKINSON R.W., ANALITIS A., FULLER G.W., BEDDOWS D., GREEN D.C., MUDWAY IS, HARRISON R.M., ANDERSON H.R., KELLY F.J. Differential health effects of short-term exposure to source-specific particles in London, UK, J Environ. int. 97, 246, 2016.

40. BAE H.-J. Effects of Short-term Exposure to $\mathrm{PM}_{10}$ and $\mathrm{PM}_{2.5}$ on Mortality in Seoul, J Environ. Health Sci. 40 (5), 346, 2014.

41. SHANG Y., SUN Z., CAO J., WANG X., ZHONG L., BI X., LI H., LIU W., ZHU T., HUANG W. Systematic review of Chinese studies of short-term exposure to air pollution and daily mortality, J Environ Int. 54, 100, 2013. 